\title{
THE FUTURE OF COLONIAL POLICY
}

THE uncertainty of the reaction of the Vichy Government to German plans for obtaining control of French West Africa has already excited alarm, not only in Great Britain and in the United States, but also among the African peoples. It is not merely the strategic issues involved that arouse concern. With the shattering, at any rate for the time being, of Anglo-French co-operation in colonial administration and development, there has come a real threat to the new and liberal ideas of trusteeship embodied in the mandate system. These fears are unlikely to be allayed by the new co-operation between France and the Axis powers, whatever form that co-operation may take.

Nowhere indeed is the contrast between the Axis powers and Great Britain more marked than in the field of colonial policy. The rule of the Axis in Africa as elsewhere would mean the subjugation of the native populations to the needs and demands of Germany and Italy, the exploitation of their resources and people in the interests of the white races alone-the complete negation of the mandate principle and a reversion to the old, evil imperialism from which Africa has slowly emerged.

There have indeed been marked differences between French and British policy, but whatever these differences, the experiments and reforms either discussed or introduced down to the fall of France all reflect the view, common to both the French and British Colonial Empires, that the native is to be treated as an end in himself, a person to be associated in one form or another with the development and administration of his country. Whereas Anglo-French co-operation in this field has been interrupted, Britain's loyalty to the principle of trusteeship remains unshaken, and indeed is reaffirmed in the developments proceeding under the policy announced by the Colonial Secretary early in the year in the Statement of Policy on Colonial Development and Welfare.

This factor may not be without some influence on the situation in Africa and on the course of the war. The Vichy Government has already aroused too much alarm in the French Colonial Empire for it to risk further alienating native opinion and support. Indeed, the whole French tradition of colonial administration is one which should make the task of General de Gaulle and the Free French forces of winning the support of the native peoples at least throughout that Empire relatively easy. The importance of wise and far-reaching propaganda should not be under-estimated, above all if it is supported by administration of the territories under the rule of Free France and of Great Britain of a type calculated to hold and encourage the loyalty of the native peoples, whose desire for a British victory has indeed already received striking demonstration.

The tactical importance of the developments in colonial policy foreshadowed in the White Paper is far from being generally realized. The practical applications of the principle of trusteeship outlined there, if wisely implemented at the present time, may even have a decisive strategic effect on the war in Africa, if it enlists fully the loyalty and enthusiasm of the African peoples. Sir William H. McLean's admirable review of the proposals and their import in his Cantor Lectures on the "Social and Economic Development of the British Colonial Empire", recently published in the Journal of the Royal Society of Arts (87, 871-881 ; $891-914 ; 1940)$ is a timely contribution which should assist in the general understanding of what is involved.

Apart altogether from tactical or strategic questions, the colonial problem has several other aspects which give it special importance at the present time. It is in the first place one of the major issues which is bound to be raised at the peace settlement. In any attempt to deal with the real causes of the present War, the question of access to raw materials will require reconsideration, and this question can scarcely be separated from that of colonial policy, administration and development.

It is fair to say that the sub-committee of the League of Nations and the Royal Institute of International Affairs have already carried out the requisite inquiries as to the facts of distribution of raw materials, and a number of important suggestions or recommendations regarding access to such materials have already been ventilated. In this sense the matter might well be regarded as in an advanced state of preparation for consideration as part of a world settlement leading to a new order after the War. Whatever specific form that settlement may take, there can be no doubt that the implementing of such a policy as that outlined in the White Paper, and the firm 
establishment and enlightened administration of the Colonial territories during the War in the spirit of trusteeship, would go far to create an atmosphere of confidence and respect essential to a settlement reconciling the claims of all races involved.

The plan outlined by the late Sir Arnold Wilson in an appendix to "More Thoughts and Talks" (Longmans, Green and Co., 1939) for a system of pooled trusteeship, in which all the African colonies were gradually pooled in such a manner as to make them serve the common good both of the white races and of the natives, deserves close study and careful consideration. It offers advantages in gradual application, without transfer or decision of sovereignty for a generation, thus affording time essential to the education of public opinion for the idea of colonial trusteeship.

Schemes of this nature involve both careful investigation and equally thorough educational work. Both alike must be put in hand now if the colonial problem is to assist and not handicap the attempts and plans for post-War reconstruction. The value of the recommendation of the Hailey report for the establishment of an African Bureau has indeed been enhanced by all that has occurred since the findings of the African Survey were published in the autumn of 1938 .

There is, however, a further and equally important respect in which the colonial questions are linked up with the problem of post-war reconstruction. The importance of the economic aspects of such construction have been repeatedly stressed, both in relation to a war strategy of organizing relief for Europe as soon as the Nazi tyranny is overthrown, and as part of a wider scheme of settlement and economic development which would aim at raising the general standard of nutrition and living in the whole continent, but especially in the more backward parts of eastern Europe. In both of these, colonial questions and resources may play a large part.

In the first place, there must be a review of outside sources, including the colonial territories, from which the deficiencies in the distressed countries can most easily be met. This will include the building up of surpluses not only in the Americas but also in tropical Africa. Besides those of cocoa, palm kernels, groundnuts and other human foodstuffs, animal foodstuffs and other raw materials must be included, some of which, such as cotton and jute, will also be required by post-war Europe. Moreover, as Dr.
Julian Huxley has pointed out, not all surpluses can be stored as such; some require processing, notably the vegetable oils. Such processing may involve the purchase of suitable machinery from countries the industry of which is not overtaxed by armaments production and, like the provisions of storage facilities, should form part of a comprehensive plan. This again may powerfully affect the economic situation in tropical Africa, where indeed it may already be necessary to buy up the surpluses if the local producers are not to starve. Such purchasing must also be done at a fair price if inroads are not to be made on the educational and social services of the territories in question.

To buy merely to destroy would be a poor answer, both to the propaganda insinuating that we are responsible for shortage in the countries overrun by the Nazis, and to their plans for the economic reorganization of Europe. The plans already envisaged by the British Government for the building up all over the world of food reserves destined for the relief of Europe may well make as important a contribution to the economic welfare of the colonial territories as to the defeat of Germany, the countering of German propaganda, and to laying the basis for a stable post-war world. The provision of proper processing and storage facilities could be made the basis of greater stability in primary production, by providing large-scale reserves functioning as buffer pools.

Such considerations alone emphasize the im. portance of the economic developments envisaged in the Statement of Policy issued last February. It is only on a secure economic foundation that schemes of social advance can be planned and carried out continuously. The lack of secure markets in the past has been the main cause of suffering to the people in some Colonies; they were unable to sell their produce and had to lower their standard of living in spite of the efforts of the Colonial Government to safeguard that standard. The real problem of raw materials, as Mr. H. D. Henderson remarks in "Colonies and Raw Materials", is that of securing a square deal for the primary producer. The first emphasis in the enlarged policy of Colonial development is accordingly on the improvement of the economic position of the Colonies. The arrangements for increased assistance from the funds of Great Britain, while related to what the Colonies can do for themselves, are intended to facilitate full and balanced development, and to place Colonial 
Governments in a position to maintain administrative, technical and social services at proper standards. They are intended to ensure the adequate financing of the research and survey work, the schemes of major capital enterprise, and the expansion of administrative and technical staffs which are essential for full and vigorous development, as well as the maintenance of an adequate standard of health and education services.

There is already much evidence that malnutrition is a factor in ill-health and inefficiency in many parts of the Colonial Empire. According to the report of the Committee of the Economic Advisory Council on "Nutrition in the Colonial Empire", malnutrition there is due first to a low standard of living; secondly, to the great ignorance and prejudice both as regards diet and the use of land; and thirdly, to the influence of diseases, particularly the widespread parasitic infections in the tropics, which react upon the state of nutrition of the individual. Improved nutrition depends largely upon economic development, and in the Colonial Empire this means primarily an improvement in agricultural development. Accordingly, in agricultural policy, the nutritional needs of the community are of first importance, and the report urges that the aim should be the establishment of a balanced agriculture for the production of commodities to be used either for direct consumption by the producer and his family, or for sale for consumption elsewhere in the territory, or for sale in overseas markets. Colonial Governments should encourage the people to grow at least a part of the foodstuffs they consume and endeavour to improve colonial dietaries by increasing the quantity of foodstuffs consumed and by increasing the variety.

It is not in eastern Europe alone that developments, designed to raise the standards of nutrition and living generally by relieving economy of some of its excessive dependence on primary products, may assist in raising standards of living and increasing social and economic stability elsewhere. Policies of social development undertaken to raise the standard of health and nutrition in the African Colonies, with their repercussion on the standard of living in those countries, should provide the same expanding market to the industrialized nations that the developments suggested by Mr. McDougall would provide in eastern Europe. The developments advocated by Lord Hailey in regard to research and adopted by the Government in the establishment of a Colonial Research Advisory Committee and in the allocation of a separate sum for Colonial research, have a direct bearing on the new order to be established in Europe, no less than in Africa.

It is indeed reassuring that such developments should be encouraged by Government action during the present struggle. Further co-operation in the study of agriculture and husbandry, of soil erosion, or of transport needs, the pooling of information about the methods used in checking the diseases to which the African is prone and for dealing with the widespread malnutrition that exists, may prove indirectly almost as valuable a contribution to the solution of some European post-war problems as directly to those of Africa itself. The prosecution of research into African problems on an adequate scale and the keeping up to date of the admirable African Survey may offer a most important contribution to reconstruction, possibly even to peace itself.

The developments at present contemplated are intended to facilitate the long-term planning which is a sine qua non of effective research in many such fields. Moreover, the emphasis thus placed on the economic development of the colonial peoples, the protection and raising of their standard of living, and their social development and training for self-government, should ensure that the position of the Colonies is viewed in all its issues at an international settlement. It affords unmistakable evidence that the principle of trusteeship is sincerely accepted and loyally fulfilled. It attests our capacity to shape within our own commonwealth at least our own form of co-operative society-in Mr. Herbert Morrison's words : "A free partnership of freely active groups, in which there is no room for mutual attempts at exploitation or for sharply differing levels of social and economic opportunity." Recognition of our responsibilities for the physical and moral welfare of these peoples and a determined effort to honour our trust are in such sharp contrast to all that has been revealed of the German attitude to such questions, of which the exclusion of the native peoples on principle from higher schools and universities enunciated by Dr. Gunther Hecht in "The Colonial Question and Racial Thought", is only one illustration that it can scarcely fail to enlist the loyalty and support of the native peoples of the African territories in a way which should effectively counter the consequences there of the collapse of France. 